\title{
The use of animal byproducts in broiler feeds. Use of animal co-products in broilers diets
}

Author(s)
Caires $\mathrm{CM}^{1 *}$
Fernandes $\mathrm{EA}^{2}$
Fagundes $\mathrm{NS}^{3}$
Carvalho $\mathrm{AP}^{4}$
Maciel MP5
Oliveira BR
1 Part of the M.Sc. dissertation of the first
author presented at FAMEV/UFU.
Professor, School of Veterinary Medicine-
FAMEV/UFU. Uberlândia, MG, Brazil.
Graduate student - FAMEV/UFU.
State Department of Environment -
SEMAD. Uberlândia, MG, Brazil.
Professor, School of Animal Science -
UNIMONTES. Montes Claros, MG, Brazil.
Undergraduate student - FAMEV/UFU,
Uberlândia, MG, Brazil.

Mail Address

Carolina Magalhães Caires

Rua Pedro Crosara Cherulli, 14. Apto1

38.400-044. Uberlândia, MG, Brazil.

E-mail: carollcaires@yahoo.com.br

\section{Keywords}

Animal co-product meals, carcass yield, meat and bone meal.

\section{ABSTRACT}

This study aimed at evaluating live performance and carcass yield of broilers fed vegetarian diets or containing different animal byproduct meals after 8 days of age. In the experiment, 1080 one-day-old male chicks were distributed in a completely randomized experimental design with 6 treatments with 6 replicates. Diets were based on corn and soybean meal, and included or not animal meals, maintaining constant levels of minerals (calcium, phosphorus, and sodium) and amino acids (methionine, cystine, lysine, and threonine), The following treatments were applied: T1. Control (corn and soybean diet); T2. Inclusion of $5 \%$ meat and bone meal (MBM); T3. Inclusion of 5\% blood meal (BM); T4. Inclusion of $5 \%$ feather meal (FM); T5. Inclusion of $5 \%$ poultry offal meal (OM); T6. Combination of meat and bone meal, feather meal, offal meal, and blood meal. Broiler weight gain, feed intake, feed conversion, livability and carcass yield were evaluated. At 35 days of age, it was verified that the combination of the four animal meals compromised weight gain. Broiler performance at 42 days of age was influenced by treatments, and the worst weight gain and true feed conversion were observed in birds fed diets with the combination of the four animal meals. The inclusion of 5\% BM negatively affected the weight gain. It is concluded that MBM, FM, and OM inclusion can be individually used with no negative influence on broiler performance or carcass yield. In addition, it reduces feed costs.

\section{INTRODUCTION}

The number of slaughtered animals has increased with animal production growth, generating large volumes of animal residues. After being submitted to treatments, these residues may be used as an alternative feedstuff in broiler diets, reducing feed costs.

The most common animal byproducts used in broiler diets are meat and bone meal, blood meal, feather meal, and poultry offal meal. These feedstuffs contain high protein levels and may partially replace soybean meal. In addition of being a protein source, meat and bone meal is also a significant source of totally available calcium ( $\mathrm{Ca}$ ) and phosphorus (P), whereas in plant feedstuffs, phosphorus is only $33 \%$ bioavailable to animals due to the presence of phytate.

Broiler performance results when animal byproducts are fed may be very variable as a function of raw material type and quality, processing temperature, use of antioxidants to maintain their quality, contamination by pathogenic microorganisms, high polyamine content, amino acid unbalance, nutrient content and digestibility, and storage conditions (Bellaver, 2001).

Sartorelli (1998) compared diets containing meat and bone meal from five different sources with a diet with dicalcium phosphate, and did not 
Caires CM, Fernandes EA, Fagundes NS, Carvalho AP, Maciel MP, Oliveira BR
The use of animal byproducts in broiler feeds. Use of animal co-products in broilers diets observe significant differences in broiler performance. Bellaver et al. (2005) showed that the inclusion of $4 \%$ meat and bone meal and $3 \%$ poultry offal meal in broiler diets did not influence live performance at 21 days of age as compared to corn-soybean meal based diets. However, at 35 and 42 days, broilers fed animal meals presented lower average weight.

The objective of the present study was to evaluate broiler live performance and carcass traits of broilers fed an all-vegetable diet and diets containing animal meals after 8 days of age.

\section{MATERIAL AND METHODS}

The experiment was carried out at the experimental poultry farm of the School of Veterinary Medicine of the Federal University of Uberlândia, MG, Brazil. In the trial, 1,080 one-day-old Avian 48 male broilers, with $43 \mathrm{~g}$ average weight, were distributed in a completely randomized experimental design into six treatments with six replicates of 30 birds each. Birds were housed in 36 floor pens, with 30 birds in each at a density of $12 \mathrm{birds} / \mathrm{m}^{2}$. Feed and water were offered ad libitum. A continuous lighting program (24h of light) was used. Average house temperature was recorded daily from 10 days up to slaughter. Average minimum and maximum temperatures recorded during the experimental period were $25.34{ }^{\circ} \mathrm{C}$ and $25.86{ }^{\circ} \mathrm{C}$, respectively.

Diets were formulated and manufactured to supply the broilers' nutritional requirements according to the recommendations of Rostagno et al. (2005). Corn, soybean meal and animal meals were chemically analyzed for feed formulation (Table 1). Diets were based in combinations of corn, soybean meal, meat and bone meal (MBM) blood meal (BM), poultry offal meal (OM), feather meal (FM), soybean oil, dicalcium phosphate, limestone, salt, and vitamin and mineral premix supplemented with synthetic amino acids (DLmethionine, L-lysine, and L-threonine), and were supplied according to a four-phase feeding program (pre-starter, starter, grower, and finisher). Animal meals started to be fed when broilers were 8 days old, and their individual inclusion percentages in the starter, grower, and finisher diets were previously established. Tables 2, 3, 4, and 5 show the ingredient and nutritional composition of the experimental diets.

Feed supplied and feed residues, as well as birds, were weighed on days $7,14,21,35$, and 42 , in order to calculate the performance parameters feed intake $(\mathrm{Fl})$, live weight $(\mathrm{LW})$ and feed conversion ratio $(\mathrm{FCR})$.
Bird mortality was recorded daily to calculate livability (L). True feed conversion ratio (TFCR) was calculated as the ratio between feed intake and weight gain, adding dead bird weights and subtracting initial chick weight.

Table 1 - Chemical composition of the animal meal, corn, and soybean meal used in the experimental diets.

\begin{tabular}{lrrrrrr}
\hline Nutrientes & $\begin{array}{c}\text { MBM } \\
(\%)\end{array}$ & $\begin{array}{r}\text { OM } \\
(\%)\end{array}$ & $\begin{array}{r}\text { FM } \\
(\%)\end{array}$ & $\begin{array}{r}\text { BM } \\
(\%)\end{array}$ & Corn & SBM \\
\hline Crude protein & 42.02 & 60.02 & 79.95 & 84.74 & 8.05 & 46.84 \\
Ether extract & 14.11 & 11.79 & 10.00 & 0.38 & 2.18 & 1.63 \\
Mineral matter & 38.02 & 11.11 & 3.46 & 3.44 & 1.93 & 6.42 \\
Calcium & 13.80 & 2.48 & 0.72 & 0.20 & 0.03 & 0.24 \\
Phosphorus & 6.81 & 1.72 & 0.38 & 0.21 & 0.24 & 0.53 \\
Dry matter & 92.06 & 97.13 & 92.23 & 93.50 & 88.00 & 89.52 \\
Dig. arginine & 3.11 & 4.03 & 5.41 & 2.73 & 0.36 & 3.15 \\
Dig. lysine & 2.03 & 3.19 & 2.13 & 5.80 & 0.20 & 2.53 \\
Dig. methionine & 0.53 & 1.07 & 0.58 & 0.83 & 0.15 & 0.60 \\
Dig. Met+Cys & 0.81 & 1.90 & 4.27 & 1.31 & 0.32 & 1.12 \\
Dig. threonine & 1.25 & 2.28 & 3.68 & 3.32 & 0.27 & 1.57 \\
Dig. tryptophan & 0.21 & 0.53 & 0.67 & 1.13 & 0.05 & 0.59 \\
\hline
\end{tabular}

\begin{tabular}{lc}
\hline \multicolumn{2}{l}{ Table 2 - Composition of the pre-starter experimental diets (1- } \\
7 days). \\
\hline Ingredients & $\mathbf{( \% )}$ \\
\hline Corn grain & 59.16 \\
Soybean meal & 35.02 \\
Soybean oil & 1.35 \\
Dicalcium phosphate & 1.98 \\
Limestone & 0.85 \\
Salt & 0.44 \\
DL-methionine & 0.38 \\
L-lysine & 0.42 \\
Starter premix & 0.20 \\
L-threonine & 0.17 \\
R\$/kg feed & 0.643 \\
Nutritional levels & \\
ME (Mcal/kg) & 2.960 \\
Crude protein (\%) & 22.11 \\
Calcium (\%) & 0.95 \\
Available phosphorus (\%) & 0.47 \\
Sodium (\%) & 0.22 \\
Dig. methionine (\%) & 0.67 \\
Dig. Met+Cys (\%) & 0.96 \\
Dig. lysine (\%) & 1.36 \\
Dig. threonine (\%) & 0.88 \\
Dig. arginine (\%) & 1.36 \\
Dig. tryptophan (\%) & 0.23 \\
\hline
\end{tabular}

MC-Mix Frango inicial SAA $2 \mathrm{~kg}\left({ }^{\circledR} \mathrm{M}\right.$-Cassab Comércio e Indústria Ltda) - Composition/kg feed - VitA 11,000Ul; D3 2,000Ul; E 16mg; folic acid $400 \mathrm{mcg}$; calcium pantothenate $10 \mathrm{mg}$; biotin $60 \mathrm{mcg}$; niacin $35 \mathrm{mg}$; pyridoxin $2 \mathrm{mg}$; riboflavin $4.5 \mathrm{mg}$; thiamin $1.2 \mathrm{mg}$; B12 $16 \mathrm{mcg}$; K 1.5mg; Se 250mcg; choline 249mg; Cu 9mg; Zn 60mg; I 1mg; Fe $30 \mathrm{mg}$; Mn 60mg; growth promoter 384mg; anticoccidial 375mg; antioxidant $120 \mathrm{mg}$.

On day 42, four birds per experimental unit representative of average body weight were selected for the evaluation of carcass traits. Birds were fasted for eight hours, slaughtered, defeathered, and 
Caires CM, Fernandes EA, Fagundes NS, Carvalho AP, Maciel MP, Oliveira BR
The use of animal byproducts in broiler feeds. Use of animal co-products in broilers diets eviscerated. The following traits were evaluated: carcass yield $(\mathrm{CY})$, breast bone-in $(\mathrm{BBI})$, deboned breast (DBB), and thighs+drum (TD) yields. Carcass yield was calculated relative to live weight before slaughter $[\% \mathrm{CY}=$ (carcass weight with no feet, neck, and head $x$ 100)/ live weight] and parts yield relative to carcass weight [Parts yield $\%=$ (parts weight $\times 100) /$ carcass weight].

\begin{tabular}{|c|c|c|c|c|c|c|}
\hline Ingredients (\%) & T1 & $\mathrm{T} 2$ & T3 & T4 & T5 & T6 \\
\hline Corn grain & 60.51 & 65.24 & 61.78 & 64.72 & 64.75 & 66.58 \\
\hline Soybean meal & 33.31 & 27.57 & 26.84 & 25.27 & 26.12 & 18.21 \\
\hline Soybean oil & 2.23 & 0.55 & 2.71 & 1.01 & 0.55 & 0.19 \\
\hline Dicalcium phosphate & 1.87 & 0.02 & 1.87 & 1.84 & 1.45 & - \\
\hline Limestone & 0.80 & 0.24 & 0.82 & 0.80 & 0.81 & 0.16 \\
\hline Salt & 0.45 & 0.40 & 0.41 & 0.41 & 0.40 & 0.40 \\
\hline DL-methionine & 0.27 & 0.29 & 0.27 & 0.24 & 0.27 & 0.25 \\
\hline L-lysine & 0.25 & 0.32 & 0.06 & 0.41 & 0.32 & 0.24 \\
\hline Starter premix1 & 0.20 & 0.20 & 0.20 & 0.20 & 0.20 & 0.20 \\
\hline L-threonine & 0.08 & 0.110 & 0.0006 & 0.06 & 0.10 & 0.02 \\
\hline Poultry offal meal & - & - & - & - & 5.00 & 3.00 \\
\hline Blood meal & - & - & 5.00 & - & - & 3.00 \\
\hline Feather meal & - & - & - & 5.00 & 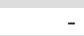 & 3.00 \\
\hline Meat and bone meal & - & 5.00 & - & - & - & 4.72 \\
\hline$R \$ / \mathrm{kg}$ feed & 0.611 & 0.547 & 0.601 & 0.570 & 0.556 & 0.499 \\
\hline \multicolumn{7}{|l|}{ Nutritional levels } \\
\hline ME (Mcal/kg) & 3.050 & 3.050 & 3.050 & 3.050 & 3.050 & 3.050 \\
\hline CP $(\%)$ & 21.14 & 21.14 & 22.24 & 21.94 & 21.14 & 23.32 \\
\hline $\mathrm{Ca}(\%)$ & 0.90 & 0.90 & 0.90 & 0.90 & 0.90 & 0.90 \\
\hline Av. P (\%) & 0.45 & 0.45 & 0.45 & 0.45 & 0.45 & 0.48 \\
\hline $\mathrm{Na}(\%)$ & 0.22 & 0.23 & 0.22 & 0.22 & 0.22 & 0.26 \\
\hline Dig. met (\%) & 0.56 & 0.57 & 0.57 & 0.51 & 0.56 & 0.54 \\
\hline Dig. $M+C(\%)$ & 0.85 & 0.85 & 0.85 & 0.85 & 0.85 & 0.85 \\
\hline Dig. lys (\%) & 1.18 & 1.18 & 1.18 & 1.18 & 1.18 & 1.18 \\
\hline Dig. thr (\%) & 0.78 & 0.78 & 0.78 & 0.78 & 0.78 & 0.78 \\
\hline Dig. $\arg (\%)$ & 1.31 & 1.26 & 1.24 & 1.29 & 1.25 & 1.27 \\
\hline Dig. $\operatorname{trp}(\%)$ & 0.22 & 0.20 & 0.24 & 0.20 & 0.20 & 0.20 \\
\hline
\end{tabular}

ME- metabolizable energy, CP - crude protein, Ca - calcium, av. P available phosphorus, $\mathrm{Na}$ - sodium met - methionine, $\mathrm{M}+\mathrm{C}$ - methionine +cystine, lys - lysine, thr - threonine, arg- arginine, trp - tryptophan. 1 MC-Mix Frango inicial SAA $2 \mathrm{~kg}\left({ }^{\circledR} \mathrm{M}-\right.$ Cassab Comércio e Indústria Ltda) - Composition/kg feed - VitA 11,000Ul; D3 2,000Ul; E 16mg; folic acid $400 \mathrm{mcg}$; calcium pantothenate $10 \mathrm{mg}$; biotin $60 \mathrm{mcg}$; niacin $35 \mathrm{mg}$; pyridoxin $2 \mathrm{mg}$; riboflavin $4.5 \mathrm{mg}$; thiamin $1.2 \mathrm{mg}$; B12 $16 \mathrm{mcg}$; K 1.5mg; Se 250mcg; choline 249mg; Cu 9mg; Zn 60mg; I 1mg; Fe $30 \mathrm{mg}$; Mn 60mg; growth promoter 384mg; anticoccidial $375 \mathrm{mg}$; antioxidant120mg

The obtained data were submitted to analysis of variance and $\mathrm{F}$ test (5\%), and means were compared by the test of Tukey at $5 \%$ using the software program "ESTAT" developed by the Department of Exact Sciences of FCAV/UNESP - Jaboticabal.

\section{RESULTS AND DISCUSSION}

Liver performance results obtained on days 14 and 21 are shown in Tables 6 and 7. Feed intake of 14-

\begin{tabular}{|c|c|c|c|c|c|c|}
\hline Ingredients (\%) & T1 & T2 & T3 & T4 & T5 & T6 \\
\hline Corn grain & 63.20 & 66.82 & 67.70 & 66.17 & 67.40 & 64.85 \\
\hline Soybean meal & 29.85 & 25.00 & 20.91 & 22.89 & 22.67 & 19.77 \\
\hline Soybean oil & 3.24 & 1.79 & 2.81 & 2.26 & 1.58 & 2.51 \\
\hline Dicalcium phosphate & 1.73 & - & 1.74 & 1.69 & 1.31 & 0.93 \\
\hline Limestone & 0.76 & 0.13 & 0.79 & 0.75 & 0.77 & 0.60 \\
\hline Salt & 0.43 & 0.40 & 0.40 & 0.40 & 0.40 & 0.40 \\
\hline DL-methionine & 0.09 & 0.26 & 0.26 & 0.21 & 0.24 & 0.04 \\
\hline L-lysine & 0.24 & 0.29 & 0.13 & 0.37 & 0.31 & 0.15 \\
\hline Grower premix ${ }^{1}$ & 0.20 & 0.20 & 0.20 & 0.20 & 0.20 & 0.20 \\
\hline L-threonine & 0.06 & 0.08 & 0.01 & 0.03 & 0.08 & - \\
\hline Poultry offal meal & 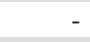 & 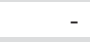 & - & - & 5.00 & 3.00 \\
\hline Blood meal & - & - & 5.00 & - & 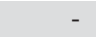 & 3.00 \\
\hline Feather meal & 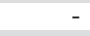 & - & - & 5.00 & - & 3.00 \\
\hline Meat and bone meal & 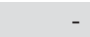 & 5.00 & 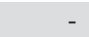 & - & 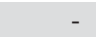 & 1.36 \\
\hline $\mathrm{R} \$ / \mathrm{kg}$ feed & 0.613 & 0.553 & 0.593 & 0.573 & 0.559 & 0.547 \\
\hline \multicolumn{7}{|l|}{ Nutritional levels } \\
\hline ME (Mcal/kg) & 3.150 & 3.150 & 3.150 & 3.150 & 3.150 & 3.150 \\
\hline$C P(\%)$ & 19.73 & 20.00 & 20.06 & 20.88 & 19.73 & 22.32 \\
\hline Ca (\%) & 0.84 & 0.84 & 0.84 & 0.84 & 0.84 & 0.84 \\
\hline Av. P (\%) & 0.42 & 0.44 & 0.42 & 0.42 & 0.42 & 0.42 \\
\hline $\mathrm{Na}(\%)$ & 0.21 & 0.23 & 0.21 & 0.21 & 0.21 & 0.24 \\
\hline Dig. met (\%) & 0.52 & 0.53 & 0.53 & 0.46 & 0.52 & 0.48 \\
\hline Dig. $M+C(\%)$ & 0.79 & 0.79 & 0.79 & 0.79 & 0.79 & 0.79 \\
\hline Dig. lys (\%) & 1.10 & 1.10 & 1.10 & 1.10 & 1.10 & 1.10 \\
\hline Dig. thr (\%) & 0.71 & 0.71 & 0.71 & 0.71 & 0.71 & 0.74 \\
\hline Dig. $\arg (\%)$ & 1.20 & 1.18 & 1.07 & 1.21 & 1.15 & 1.23 \\
\hline Dig. $\operatorname{trp}(\%)$ & 0.20 & 0.18 & 0.21 & 0.18 & 0.18 & 0.21 \\
\hline
\end{tabular}

ME- metabolizable energy. CP - crude protein. Ca - calcium. av. P available phosphorus. $\mathrm{Na}$ - sodium met - methionine. $\mathrm{M}+\mathrm{C}$ methionine+cystine. lys - lysine. thr - threonine. arg- arginine. trp tryptophan. 1 MC-Mix Frango engorda SAA $2 \mathrm{~kg}\left({ }^{\circledR} \mathrm{M}\right.$-Cassab Comércio e Indústria Ltda) - Composition/kg feed - VitA 9.000Ul; D3 $1.600 \mathrm{UI}$; E $14 \mathrm{mg}$; folic acid $300 \mathrm{mcg}$; calcium pantothenate 9mg; biotin $50 \mathrm{mcg}$; niacin $30 \mathrm{mg}$; pyridoxin $1.8 \mathrm{mg}$; riboflavin $4 \mathrm{mg}$; thiamin $1 \mathrm{mg} ; \mathrm{B} 12$ 12mcg; K 1.5mg; Se 250mcg; choline 219mg; Cu 9mg; Zn $60 \mathrm{mg}$; I 1mg; Fe 30mg; Mn 60mg; growth promoter $385 \mathrm{mg}$; anticoccidial 550mg; antioxidant $120 \mathrm{mg}$.

day-old broilers ranged between 0.650 and $0.737 \mathrm{~kg}$, and between 1.298 and $1.452 \mathrm{~kg}$ when broilers were evaluated on day 21; however, there were no significant differences among treatments ( $p>0.05$ ). Live weight ranged between 0.503 and $0.528 \mathrm{~kg}$ on day 14 and between 0.986 and $1.028 \mathrm{~kg}$ on day 21 , and again no differences were detected among treatments $(p>0.05)$. All the other evaluated performance parameters were not influenced by the treatments. Sartorelli (1998), Junqueira et al. (2000), and Faria Filho et al. (2002) did not find significant differences in broiler performance when MBM was included in the feeds during the same period. Bellaver et al. (2005), comparing the inclusion of $4 \%$ meat and bone meal, $3 \%$ poultry offal meal, and vegetable diets, did not observe any influence of diets on 21-day-old broiler performance. On the other hand Kamwa (1997) showed that diets containing, in addition to soybean 
Caires CM, Fernandes EA, Fagundes NS, Carvalho AP, Maciel MP, Oliveira BR
The use of animal byproducts in broiler feeds. Use of animal co-products in broilers diets

\begin{tabular}{|c|c|c|c|c|c|c|}
\hline Ingredients (\%) & T1 & T2 & T3 & T4 & T5 & T6 \\
\hline Corn grain & 59.36 & 61.20 & 66.88 & 65.13 & 62.07 & 64.80 \\
\hline Soybean meal & 32.33 & 29.34 & 20.72 & 22.91 & 26.47 & 18.65 \\
\hline Soybean oil & 5.07 & 4.04 & 4.13 & 3.61 & 3.69 & 2.95 \\
\hline Dicalcium phosphate & 1.56 & - & 1.58 & 1.52 & 1.13 & \\
\hline Limestone & 0.75 & 0.23 & 0.79 & 0.75 & 0.75 & 0.32 \\
\hline Salt & 0.40 & 0.33 & 0.36 & 0.36 & 0.34 & 0.26 \\
\hline DL-methionine & 0.08 & 0.08 & 0.12 & 0.06 & 0.06 & 0.04 \\
\hline L-lysine & 0.11 & 0.11 & 0.09 & 0.31 & 0.14 & 0.09 \\
\hline Starter premix ${ }^{1}$ & 0.30 & 0.30 & 0.30 & 0.30 & 0.30 & 0.30 \\
\hline L-threonine & - & - & - & - & - & - \\
\hline Poultry offal meal & - & - & - & - & 5.00 & 3.00 \\
\hline Blood meal & - & 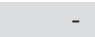 & 5.00 & - & - & 3.00 \\
\hline Feather meal & - & - & - & 5.00 & - & 3.00 \\
\hline Meat and bone meal & - & 4.33 & - & - & - & 3.56 \\
\hline$R \$ / k g$ feed & 0.578 & 0.528 & 0.572 & 547 & 0.530 & 0.496 \\
\hline \multicolumn{7}{|l|}{ Nutritional levels } \\
\hline ME (Mcal/kg) & 3.200 & 3.200 & 3.200 & 3.200 & 3.200 & 3.200 \\
\hline$C P(\%)$ & 20.28 & 20.92 & 19.76 & 20.63 & 20.71 & 22.59 \\
\hline $\mathrm{Ca}(\%)$ & 0.80 & 0.80 & 0.80 & 0.80 & 0.80 & 0.80 \\
\hline$A v . P(\%)$ & 0.39 & 0.40 & 0.39 & 0.39 & 0.39 & 0.40 \\
\hline $\mathrm{Na}(\%)$ & 0.20 & 0.20 & 0.20 & 0.20 & 0.20 & 0.20 \\
\hline Dig. met (\%) & 0.48 & 0.48 & 0.50 & 0.43 & 0.47 & 0.45 \\
\hline Dig. $M+C(\%)$ & 0.75 & 0.75 & 0.75 & 0.75 & 0.75 & 0.75 \\
\hline Dig. Iys (\%) & 1.05 & 1.05 & 1.05 & 1.05 & 1.05 & 1.05 \\
\hline Dig. thr (\%) & 0.68 & 0.68 & 0.69 & 0.68 & 0.68 & 0.74 \\
\hline Dig. $\arg (\%)$ & 1.26 & 1.28 & 1.05 & 1.20 & 1.24 & 1.24 \\
\hline Dig. $\operatorname{trp}(\%)$ & 0.21 & 0.20 & 0.21 & 0.18 & 0.20 & 0.20 \\
\hline
\end{tabular}

ME- metabolizable energy, CP - crude protein, Ca - calcium, av. P available phosphorus, $\mathrm{Na}$ - sodium met - methionine, $\mathrm{M}+\mathrm{C}$ methionine+cystine, lys - lysine, thr - threonine, arg- arginine, $\operatorname{trp}$ tryptophan. 1 MC-Mix Frango abate $3 \mathrm{~kg}\left({ }^{\circledR} \mathrm{M}\right.$-Cassab Comércio e Indústria Ltda) - Composition/kg feed - VitA 2,700Ul; D3 450Ul; E 4.5mg; calcium pantothenate $3.6 \mathrm{mg}$; biotin $13.5 \mathrm{mcg}$; niacin $4.5 \mathrm{mg}$; pyridoxin 360mcg; riboflavin $900 \mathrm{mcg}$; thiamin $270 \mathrm{mcg}$; B12 $2.7 \mathrm{mcg}$; K3 450mcg; Se 180mcg; choline 130mg; methionine 906mg; Cu 9mg; Zn 60mg; I 1mg; Fe 30mg; Mn 60mg; antioxidant 120mg. meal, meat and bone meal, poultry offal meal, or a combination of meat and bone meal, feather meal, and poultry offal meal, broilers presented better body weight and feed conversion ratio at 21 days of age as compared to the diet containing only soybean meal.

Table 8 shows the performance results obtained on day 35 . The parameters feed intake, feed conversion ratio, true feed conversion ratio, and livability were not affected ( $p>0.05$ ) by the treatments. However, the live weight of birds fed the combination of animal meals (T6) was significantly lower $(p<0.05)$. Sartorelli (1998) and Junqueira et al. (2000) did not find significant performance differences when feeding broilers with MBM in the same period, whereas Faria Filho et al. (2002) found that the inclusion of $6 \%$ MBM resulted in lower feed intake and lower weight gain in that period, and argued that performance was impaired because the diets were formulate on total amino acid basis and not on digestible amino acids. Bellaver et al. (2005) comparing the inclusion of $4 \%$ meat and bone meal, $3 \%$ poultry offal meal, and vegetarian diets, obtained lower average broiler weight on day 35 when animal meals were fed, as compared to the vegetarian diet.

The worse performance observed in the present study when the combination of the four different animal meals (MBM, BM, OM and FM) were fed may be related to the high crude protein levels of the starter and grower diets $(23.32 \%$ and $22.32 \%$, respectively) and amino acid levels, particularly of threonine and

\begin{tabular}{|c|c|c|c|c|c|}
\hline Treatment & Feed intake $(\mathrm{kg})$ & Live weight $(\mathrm{kg})$ & True FCR & FCR & Livability (\%) \\
\hline 1 & $0.683^{a}$ & $0.507^{a}$ & $1.446^{\mathrm{a}}$ & $1.063^{\mathrm{a}}$ & $96.66^{a}$ \\
\hline 2 & $0.705^{a}$ & $0.513^{a}$ & $1.501^{\mathrm{a}}$ & $1.089^{a}$ & $100.00 a$ \\
\hline 3 & $0.674^{a}$ & $0.503^{a}$ & $1.458^{a}$ & $1.083^{a}$ & $97.77^{a}$ \\
\hline 4 & $0.663^{a}$ & $0.504^{a}$ & $1.425^{a}$ & $1.061^{a}$ & $97.77^{a}$ \\
\hline 5 & $0.650^{a}$ & $0.512^{a}$ & $1.380^{a}$ & $1.041^{\mathrm{a}}$ & $98.33^{a}$ \\
\hline 6 & $0.737^{a}$ & $0.528^{a}$ & $1.500^{\mathrm{a}}$ & $1.092^{\mathrm{a}}$ & $97.77^{a}$ \\
\hline CV & 8.96 & 3.54 & 6.99 & 4.69 & 2.88 \\
\hline
\end{tabular}

T1-control feed; T2-Inclusion of 5\% de MBM; T3-Inclusion of 5\% BM; T4-Inclusion of 5\% FM; T5-Inclusion of 5\% OM; T6- Combination of MBM, $B M, F M$, and OM. Means followed by different letters in the same column are significantly different by the testo $f$ Tukey ( $p<0.05$ ).

\begin{tabular}{|c|c|c|c|c|c|}
\hline Treatment & Feed intake $(\mathrm{kg})$ & Live weight $(\mathrm{kg})$ & True FCR & FCR & Livability (\%) \\
\hline 1 & $1.341^{\mathrm{a}}$ & $1.003^{a}$ & $1.014^{a}$ & $1.338^{a}$ & $95.55^{a}$ \\
\hline 2 & $1.386^{a}$ & $1.028^{a}$ & $1.398^{a}$ & $1.348^{a}$ & $98.89^{a}$ \\
\hline 3 & $1.319^{a}$ & $0.986^{a}$ & $1.396^{\mathrm{a}}$ & $1.340^{a}$ & $97.22^{\mathrm{a}}$ \\
\hline 4 & $1.374^{\mathrm{a}}$ & $0.996^{a}$ & $1.423^{a}$ & $1.378^{a}$ & $96.66^{a}$ \\
\hline 5 & $1.298^{a}$ & $0.999^{a}$ & $1.336^{a}$ & $1.297^{a}$ & $96.66^{a}$ \\
\hline 6 & $1.452^{a}$ & $1.014^{a}$ & $1.449^{a}$ & $1.431^{\mathrm{a}}$ & $95.00 a$ \\
\hline $\mathrm{CV}$ & 8.97 & 4.24 & 8.26 & 8.33 & 3.51 \\
\hline
\end{tabular}

T1-control feed; T2-Inclusion of 5\% de MBM; T3-Inclusion of 5\% BM; T4-Inclusion of 5\% FM; T5-Inclusion of 5\% OM; T6- Combination of MBM, $\mathrm{BM}, \mathrm{FM}$, and OM. Means followed by different letters in the same column are significantly different by the testo $f$ Tukey ( $p<0.05)$. 
Caires CM, Fernandes EA, Fagundes NS, Carvalho AP, Maciel MP, Oliveira BR
The use of animal byproducts in broiler feeds. Use of animal co-products in broilers diets arginine in the grower diet, as compared to the other treatments. According to Leclercq (1996), excessive protein is catabolized and excreted as uric acid by birds. Based on the principle that the estimated metabolic cost to incorporate one amino acid into the protein chain is $4 \mathrm{~mol}$ of ATP, and that the estimated cost to excrete an amino acid ranges between 6 and $18 \mathrm{~mol}$ of ATP, it is concluded that the excretion of excessive amino acids has a high metabolic or calorie cost. This may have impaired the performance of the birds fed the diet with excessive protein and amino acids, and the energy that should be used for muscle accretion was diverted to nitrogen excretion.

Feed intake, live weight, feed conversion ratio, and livability results of 42-day-old broilers are shown in Table 9. The combination of the four animal meals again resulted in the lowest live weight $(p<0.05)$ followed by the treatment with BM inclusion, and the birds fed the diets soybean meal, MBM, FM, and OM diets presented better live weight.

The worst true feed conversion ratio $(p<0.05)$ was observed in birds fed the diet that included the four animal meals are compared to the other treatments.

The other studied performance parameters were not influenced ( $p>0.05)$ by the treatments. These results agree with the findings of Sartorelli (1998) and Junqueira et al. (2000), who did not find significant performance differences when MBM was added in the feeds fed to birds of the same age. In contrast, Faria Filho et al. (2002) included 6\% MBM in broiler diets and observed lower feed intake and weight gain in the same period.

When the levels of the individual animal meals are considered, the results of the present study differ from those of Donkoh et al. (1999), who concluded that the inclusion of 5 and $7.5 \%$ BM promoted better weight and feed conversion ratio as compared to the treatments with zero or 2.5\% BM. Guichard (2008) also verified that the use of $1 \%$ feather meal in broiler diets resulted in better weight gain than the diet based on corn and soybean meal.

The poor performance obtained with the combined

\begin{tabular}{cccccc}
\hline \multicolumn{2}{c}{ Table 8 - Performance of 35-day-old broilers fed diets containing animal meals or not. } & & \\
\hline Treatment & Feed intake $\mathbf{( k g )}$ & Live weight $\mathbf{( k g )}$ & True FCR & FCR & Livability (\%) \\
\hline 1 & $3.655^{\mathrm{a}}$ & $2.392^{\mathrm{a}}$ & $1.505^{\mathrm{a}}$ & $1.527^{\mathrm{a}}$ & $92.22^{\mathrm{a}}$ \\
2 & $3.696^{\mathrm{a}}$ & $2.376^{\mathrm{a}}$ & $1.461^{\mathrm{a}}$ & $1.555^{\mathrm{a}}$ & $89.46^{\mathrm{a}}$ \\
3 & $3.723^{\mathrm{a}}$ & $2.335^{\mathrm{a}}$ & $1.528^{\mathrm{a}}$ & $1.596^{\mathrm{a}}$ & $89.44^{\mathrm{a}}$ \\
4 & $3.702^{\mathrm{a}}$ & $2.361^{\mathrm{a}}$ & $1.488^{\mathrm{a}}$ & $1.519^{\mathrm{a}}$ & $88.88^{\mathrm{a}}$ \\
5 & $3.644^{\mathrm{a}}$ & $2.404^{\mathrm{a}}$ & $1.479^{\mathrm{a}}$ & $1.565^{\mathrm{a}}$ & $93.33^{\mathrm{a}}$ \\
6 & $3.356^{\mathrm{a}}$ & $2.146 \mathrm{~b}$ & $1.538^{\mathrm{a}}$ & 6.56 & 6.79 \\
CV & 6.05 & 3.23 & 6.05 & $\mathrm{a}$ \\
\hline
\end{tabular}

T1-control feed; T2-Inclusion of 5\% de MBM; T3-Inclusion of 5\% BM; T4-Inclusion of 5\% FM; T5-Inclusion of 5\% OM; T6- Combination of MBM, BM, FM, and OM. Means followed by different letters in the same column are significantly different by the testo $f$ Tukey ( $p<0.05$ ).

\begin{tabular}{|c|c|c|c|c|c|}
\hline Treatment & Feed intake $(\mathrm{kg})$ & Live weight $(\mathrm{kg})$ & True FCR & FCR & Livability (\%) \\
\hline 1 & $5.397^{a}$ & $2.994^{\mathrm{a}}$ & $1.756 b$ & $1.806^{\mathrm{a}}$ & $88.88^{a}$ \\
\hline 2 & $5.999^{a}$ & $2.945^{a}$ & $1.841 \mathrm{ab}$ & $2.035^{a}$ & $81.73^{a}$ \\
\hline 3 & $5.677^{a}$ & $2.745 b c$ & $1.886 a b$ & $2.070^{a}$ & $82.77^{a}$ \\
\hline 4 & $5.372^{a}$ & $2.868 a b$ & $1.785 b$ & $1.873^{a}$ & $87.22^{a}$ \\
\hline 5 & $5.589^{a}$ & $3.004 a$ & $1.778 \mathrm{~b}$ & $1.860^{a}$ & $88.33^{a}$ \\
\hline 6 & $5.620^{a}$ & $2.664 c$ & $2.045 a$ & $2.111^{a}$ & $88.88^{a}$ \\
\hline CV & 9.11 & 3.60 & 7.29 & 9.55 & 8.63 \\
\hline
\end{tabular}

T1-control feed; T2-Inclusion of 5\% de MBM; T3-Inclusion of 5\% BM; T4-Inclusion of 5\% FM; T5-Inclusion of 5\% OM; T6- Combination of MBM, $B M, F M$, and OM. Means followed by different letters in the same column are significantly different by the testo $f$ Tukey ( $p<0.05$ ).

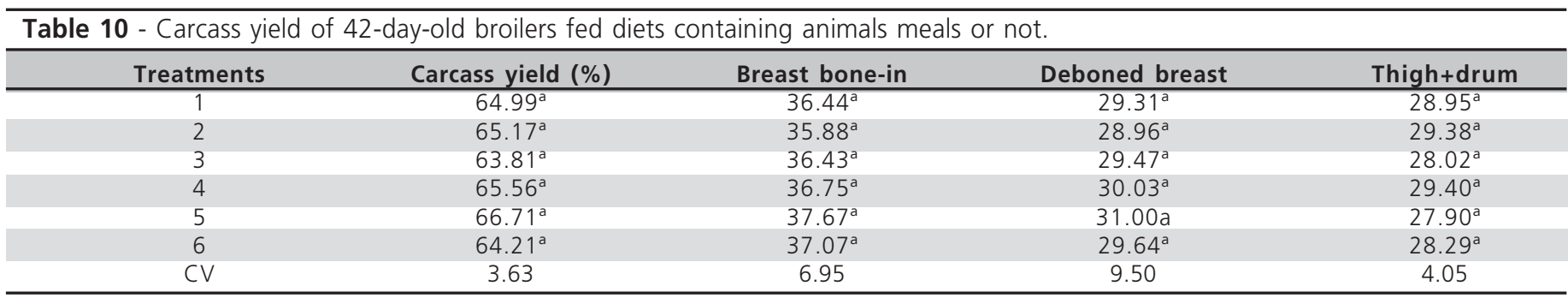

T1-control feed; T2-Inclusion of 5\% de MBM; T3-Inclusion of 5\% BM; T4-Inclusion of 5\% FM; T5-Inclusion of 5\% OM; T6- Combination of MBM, $B M, F M$, and OM.Means followed by different letters in the same column are significantly different by the testo $f$ Tukey ( $p<0.05$ ). 


\section{Caires CM, Fernandes EA, Fagundes NS, Carvalho AP, Maciel MP, Oliveira BR}

The use of animal byproducts in broiler feeds. Use of animal co-products in broilers diets inclusion of the four animal meals (T6) and blood meal (T3) may be related to a possible amino acid unbalance, as well as to the high protein levels of the T6 feeds during the experimental period, of $23.32 \%, 22.32 \%$, and $22.59 \%$ in the starter, grower, and finisher diets, respectively.

Carcass yield and breast bone-in, deboned breast, and thigh+drum yields are presented in Table 10. The studied parameters were not influenced ( $p>0.05)$ by the use of animal meals. These findings are consistent with those of Junqueira et al. (2000) and Faria Filho et al. (2002), who did not obtain significant carcass yield differences when MBM was included in the diets. The data obtained in the present study show that the dietary inclusion of animal meals did not compromise carcass yield; however, it reduced feed cost in an average of 9\% (Tables 3, 4, and 5).

\section{CONCLUSIONS}

The obtained results allowed us to conclude that the individual inclusion of $5 \%$ meat and bone meal, feather meal, or poultry offal meal in broiler diets did not compromise live performance or carcass yield, and allowed feed cost reduction.

\section{REFERENCES}

Bellaver C. Ingredientes de origem animal destinado à fabricação de rações. Anais do Simpósio Sobre Ingredientes na Alimentação Animal; 2001; Campinas, São Paulo. Brasil.

Bellaver C, Costa CA, Avila VS, Fraha M, Lima GJ, Hackenhar L, Baldi L. Substituição de farinhas de origem animal por ingredientes de origem vegetal em dietas para frangos de corte. Ciência Rural 2005; 35(3):671-677.

Donkoh A, Atuahene CC, Anang DM. Chemical composition of solar-dried blood meal and its effect on performance of broiler chickens. Animal Feed Science and Technology 1999; 81:299-307.

ESTAT. Sistema para análise estatística: V.2.0 Jaboticabal: FCAV/ Departamento de Ciências Exatas.

Faria Filho DE, Faria DE, Junqueira OM, Rizzo MF, Araújo LF, Araújo CSS. Avaliação da farinha de carne e ossos na limentação de frangos de corte. Revista Brasileira de Ciência Avícola 2002; 4(1):01-09.

Guichard BL. Effect of feather meal feeding on the body weight and feather development of broilers. European Journal of Scientfic Research 2008; 24(3):404-409.

Junqueira OM, Farias Filho DE, Faria DE, Araujo LF, Rizzo M F, Araujo CS, Andreotti MO, Cancherini LC. Farinha de carne e ossos em dietas de frangos de corte. Anais da $37^{\circ}$ Reunião Anual da Sociedade Brasileira de Zootecnia; 2000; Viçosa, Minas Gerais. Brasil: Sociedade
Brasileira de Zootecnia; 2000.

Kamwa EB. Utilização de diferentes ingredientes de origem animal na alimentação de frango de corte: avaliação do desempenho zootécnico e da viabilidade econômica [dissertação]. Curitiba (PR): Universidade Federal do Paraná; 1997. 44p.

Leclercq B. Les rejet azote issus de láviculture: importance et progress envisageables. INRA Productions Animales 1996; 9:91-101.

Rostagno HS, Albino LF, Donzele JL, Gomes PC, Oliveira RF, Lopes DC, Ferreira AS, Barreto SL Tabelas brasileiras para aves e suínos: composição dos alimentos e exigências nutricionais. Viçosa, MG: UFV; 2005. $141 p$.

Sartorelli SAA. Uso de farinha de carne e ossos em rações de frango de corte [dissertação]. Lavras (MG): Universidade Federal de Lavras; 1998. 